\title{
Flood susceptibility assessment in a highly urbanized alluvial fan: the case study of Sala Consilina (southern Italy)
}

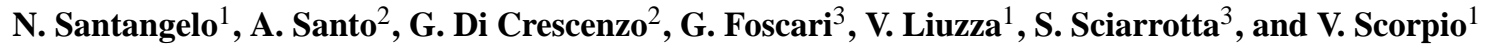 \\ ${ }^{1}$ Department of Earth Sciences, University of Naples Federico II, Largo San Marcellino 10, Napoli, Italy \\ ${ }^{2}$ Department of Hydraulic, Geotechnical and Environmental Engineering, Applied Geology Division, \\ University of Naples Federico II, Italy \\ ${ }^{3}$ University of Salerno, Political, Social and Communications Science Department, Italy
}

Received: 1 March 2011 - Revised: 16 September 2011 - Accepted: 19 September 2011 - Published: 17 October 2011

\begin{abstract}
This paper deals with the risk assessment to alluvial fan flooding at the piedmont zone of carbonate massifs of the southern Apennines chain (southern Italy). These areas are prime spots for urban development and are generally considered to be safer than the valley floors. As a result, villages and towns have been built on alluvial fans which, during intense storms, may be affected by flooding and/or debris flow processes.

The study area is located at the foothills of the Maddalena mountains, an elongated NW-SE trending ridge which bounds to the east the wide intermontane basin of Vallo di Diano. The area comprises a wide detrital talus (bajada) made up by coalescent alluvial fans, ranging in age from the Middle Pleistocene to the Holocene. Historical analysis was carried out to ascertain the state of activity of the fans and to identify and map the zones most hit by past flooding. According to the information gathered, the Sala Consilina fans would appear prone to debris flows; in the past these processes have produced extensive damage and loss of life in the urban area. The watershed basins feeding the fans have very low response times and may produce debris flow events with high magnitudes. Taking into account the historical damage, the fan surface morphology, and the present urban development (street orientation and hydraulic network), the piedmont area was zoned and various susceptibility classes were detected. These results may represent a useful tool for studies aiming at territorial hazard mapping and civil protection interventions.
\end{abstract}

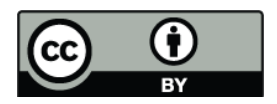

Correspondence to: N. Santangelo (nicsanta@unina.it)

\section{Introduction}

In recent years many geological, geomorphological and hydraulic engineering studies have focused on assessing natural hazard and risk conditions (Aleotti and Chowdhury, 1999). In Italy these studies have mainly sought to assess landslide hazards in mountain and hill areas (Leone et al., 1996, Fell and Hartford, 1997; Aleotti and Chowdhury, 1999; Castelli et al., 2002; Lee and Jones, 2004; Cascini et al., 2005; JTC1,2008 ) and flood hazards in the floodplains (Canuti and Casagli, 1996; Van Westen, 2000, Guzzetti et al., 2005). Less attention has been paid to hazard assessment in foothills, where flooding processes occur within alluvial fans. According to NRC (1996), "alluvial fan flooding is a type of flood hazard that occurs only on alluvial fans. It is characterized by flow uncertainty so great that this uncertainty cannot be set aside in realistic assessment of flood risk or in the reliable mitigation of the hazard".

The overall aim of this paper is to depict the susceptibility conditions to alluvial events in the context of a highly urbanized alluvial fan. Susceptibility is defined as the likelihood of a dangerous event occurring in an area on the basis of local terrain conditions. Generally this term is largely used in landslide hazard assessment but can be extended to all types of natural hazards. In this sense, it is the degree to which an area can be affected by future dangerous events, i.e. an estimate of "where" the events are likely to occur. Susceptibility does not consider the temporal probability of the event (e.g. when or how frequently the dangerous events may occur). This approach is useful for areas, like that under study, where it is difficult to obtain enough information concerning the temporal probability of an event occurring.

Published by Copernicus Publications on behalf of the European Geosciences Union. 
Along the Southern Apennines, piedmont areas are a widespread geomorphic unit and are generally located at the foot of steep slopes bordering the main carbonate massifs of the region. The main alluvial fans are fed by drainage basins with high relief energy and short response times. In these basins runoff is generally low and ephemeral, occurring mainly during the most heavy rainfall periods. Short but particularly intense rainfall events can produce flash floods with large debris loads, which are extremely hazardous for the resident population and the urban settlements sited in piedmont areas. During the last few centuries until now, many of these basin/fan systems have been affected by severe flooding that has produced serious damage and loss of life. Since the return period of these severe rainfall events is very high (greater than $50 \mathrm{yr}$ ), there is limited awareness of the actual hazard conditions on the part of the local community, as these fans to the untrained eye look like the most suitable sites for a wide variety of development ranging from farming to housing, industrial facilities, or transportation routes. This paper suggests a method which can be used to reconstruct the susceptibility scenarios of a fan system, particularly when it is highly urbanized and the natural erosion and depositional areas may be hidden or strongly modified by human activity. The results obtained may be useful in subsequent studies aiming to assess hazard conditions at a local scale for suitable urban planning.

\section{Flood hazard on alluvial fans}

Alluvial fans are common landforms at mountain fronts due to the sudden reduction in fluvial energy caused by a change in topographic gradients (Bull, 1968, 1977), although they can also develop in the interior of mountain areas (Harvey, 1997). Fans are formed by and can be subject to floods, debris floods, and debris flows (hydrogeomorphic processes), with resulting damage to infrastructure and loss of life (Van Dine, 1985; NRC, 1996). Central to hazard recognition is the need to identify the specific hydrogeomorphic process because each process has different associated hazard characteristics. For example, debris flows can have peak discharges 5 to 40 times greater than floods, while debris floods only have relative peak discharges up to twice those of flood discharges (Hungr et al., 2001). Hence, the frequency and severity of events vary by many orders of magnitude (Kellerhalls and Church, 1990). Unlike the case of floodplains, where water levels and associated return periods provide an objective and widely accepted classification of the degree of exposure, there are no broadly accepted standards for classifying hazards on fans.

The hazard zonation of a fan area is generally done on the basis of past debris flow events occurring in the same basin (Flentje et al., 2000) or on the predictions of the magnitude of possible future debris flows (Laigle and Marchi, 2000). Since the magnitude of an event is related to the energy of the water sediment flow and the total solid volume involved, a good prediction can be made when both such important elements are quantified with reasonable accuracy.

In particular, the debris volumes that can be deposited on a debris fan during a debris flow may be predicted by means of well-known empirical or theoretical approaches (D'Agostino, 1996; Marchi and Tecca, 1995; Bottino and Crivellari, 1998). In general, application of one method does not exclude others, as comparison of the results obtained with different available criteria is often useful. At present there are no rigorous methods which allow the exact probability of debris flow occurrence to be strictly determined, as this is based either on physically measured characteristics of a catchment or on statistical analysis.

According to several sources (Kellerhalls and Churh, 1990; NRC, 1996), the most common basic approach consists, for a given basin/fan system, in an accurate field survey both of the watershed basin and of the fan, aiming to detect the active zone of erosion and deposition, accompanied by office investigations and interviews aiming to reconstruct past events.

\section{The study area}

Our study area was the town of Sala Consilina, situated in the Vallo di Diano intermontane basin (Fig. 1) at the base of its eastern mountain front (Mts. Maddalena) which is characterised by a wide system of coalescing alluvial fans. In particular, six fan systems were taken into consideration as they were recognised by a previous study (Santangelo et al., 2006) as the most hazardous in the whole piedmont area on the basis of their main morphometric features. Moreover, the area is highly urbanised (Fig. 2) and in recent centuries was affected by severe flood events.

The Vallo di Diano is the largest intermontane basin in the southern Apennines (Santangelo, 1991; Ascione et al.,1992). The main landforms characterizing the basin comprise an elongated, almost flat plain and a rectilinear mountain front on the eastern side. The plain has an average elevation of $450 \mathrm{~m}$ a.s.l. and corresponds to a slightly dissected fluviolacustrine and palustrine surface of late PleistoceneHolocene age (Ascione et al., 1992). The eastern side of the basin is a fault-generated, mature mountain front (Fig. 1), with an average elevation of $970 \mathrm{~m}$ (the highest top reaching $1500 \mathrm{~m}$ a.s.l.). It is $41 \mathrm{~km}$ long and has a fairly welldefined rectilinear shape. The base of the eastern range is, for the most part, covered by a thick system of coalescing alluvial fans, hitherto grouped into two main orders: an older, inactive system of middle Pleistocene fans and a younger system of partly active, late PleistoceneHolocene fans entrenched in the previous generation (Santangelo, 1991; Santangelo et al., 2006). Based on historical reports and a comparison between present-day and early 20th century topographic maps, very recent progradation lobes are 


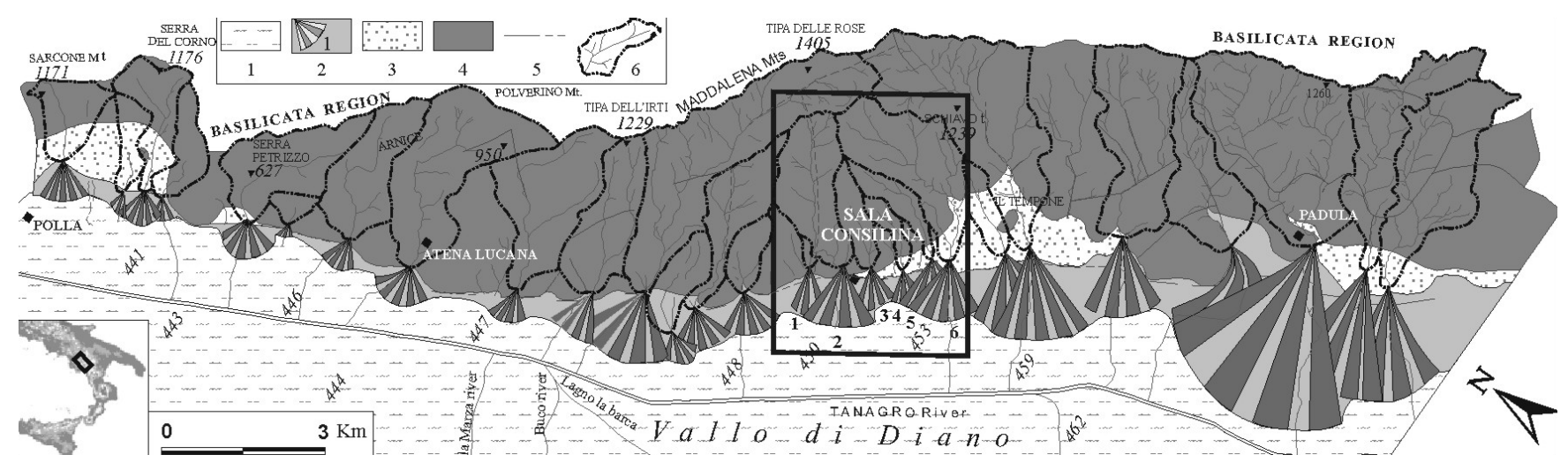

Fig. 1. Geological sketch map of the Vallo di Diano basin (after Santangelo et al., 2006, modified.) Legend: (1) lacustrine silt and clay (upper Pleistocene); (2) recent alluvial fan (upper Pleistocene-Holocene); (3) ancient alluvial fan (middle Pleistocene); (4) Mesozoic dolostones and tertiary flysch; (5) fault; (6) watershed basin. The rectangle indicates the study area.

recognized on the younger fans. They are found between Polla and Padula (Fig. 1), where the most important and welldocumented catastrophic floods date back to 1857 (this event severely damaged the San Lorenzo Carthusian monastery at Padula (Budetta et al., 2000). The main rock type cropping out in the basins feeding the Sala Consilina fans is Mesozoic dolostones (http://www.apat.gov.it/media/carta geologica_italia/tavoletta.asp?foglio=199) and the main debris sources are represented by the most jointed portions of the carbonate succession. From a climatic point of view most of the areas show a SW exposure; the general climate is humid temperate with mean annual rainfall ranging from 1000 to $2000 \mathrm{~mm}$ and maximum monthly values of $160-190 \mathrm{~mm}$, chiefly occurring during the autumn and spring. There are different types of land use in the study area, ranging from deciduous forest or barren land in the drainage basins to olive orchards on the fans.

\section{Methods}

The procedure chosen to reconstruct the fan flooding scenarios is based on a qualitative approach and closely adheres to the three-step procedure to alluvial fan flooding determination recently outlined by NRC (1996) that can be summarized as follows:

1. Recognition and characterization of the alluvial fan landform.

2. Defining the nature of the alluvial fan environment and the location of active erosion and deposition.

3. Defining and characterizing areas of "100-yr" alluvial fan flooding.

These guidelines are based in part on the following tenet: “... the area of deposition on an alluvial fan shifts with time, but the next episode of flooding is more likely to occur where the most recent deposits have been laid down than where deposits of greatest antiquity occur" (NRC, 1996, p. 62).

For the first and second steps we conducted detailed geomorphological and geological analysis both in the laboratory (air photo interpretation, topographic map analysis, GIS and DEM elaboration) and in the field.

The six catchments and the corresponding alluvial fans were identified and digitized within a Geographical Information System (GIS) using 1:5000 scale topographic maps; in this way the main morphometric characteristics were obtained. Analysis of the topographic maps allowed the detection and mapping of the active/inactive portion of each alluvial fan system. Also, the fan lateral boundaries were defined on the basis of change in the shapes of contour lines. Due to the high degree of urbanization it was necessary to produce a detailed steepness map and a digital elevation model (cell size $5 \mathrm{~m}$ ), deriving them from a 1:2000 topographic map edited by the Sala Consilina municipality, to identify the main topographic anomalies of the fan surface. The subsequent field survey covered both the watershed basin and the fan area. In the first case it aimed to evaluate the presence of superficial deposits and the stability conditions of the mountainsides. In the fan area it focused on defining particle size distributions and facies association of fan deposits. All this information was gathered into a geologicalgeomorphological map (1:5000). Particular attention was also given to the survey of the hydraulic network conditions in the fan areas: urbanization has altered drainage patterns, waters are forced to flow through tubes with very small sections, and most flooding is likely to occur along streets. For this reason a detailed map of hydraulic and road network conditions (1:2000) was constructed.

For the third step historical analysis was performed to find evidence in the literature and in the archives of past floods, aiming to enhance our knowledge both of the event type and to locate areas affected by flooding in the past. This analysis allowed the construction of a "historical events map" 


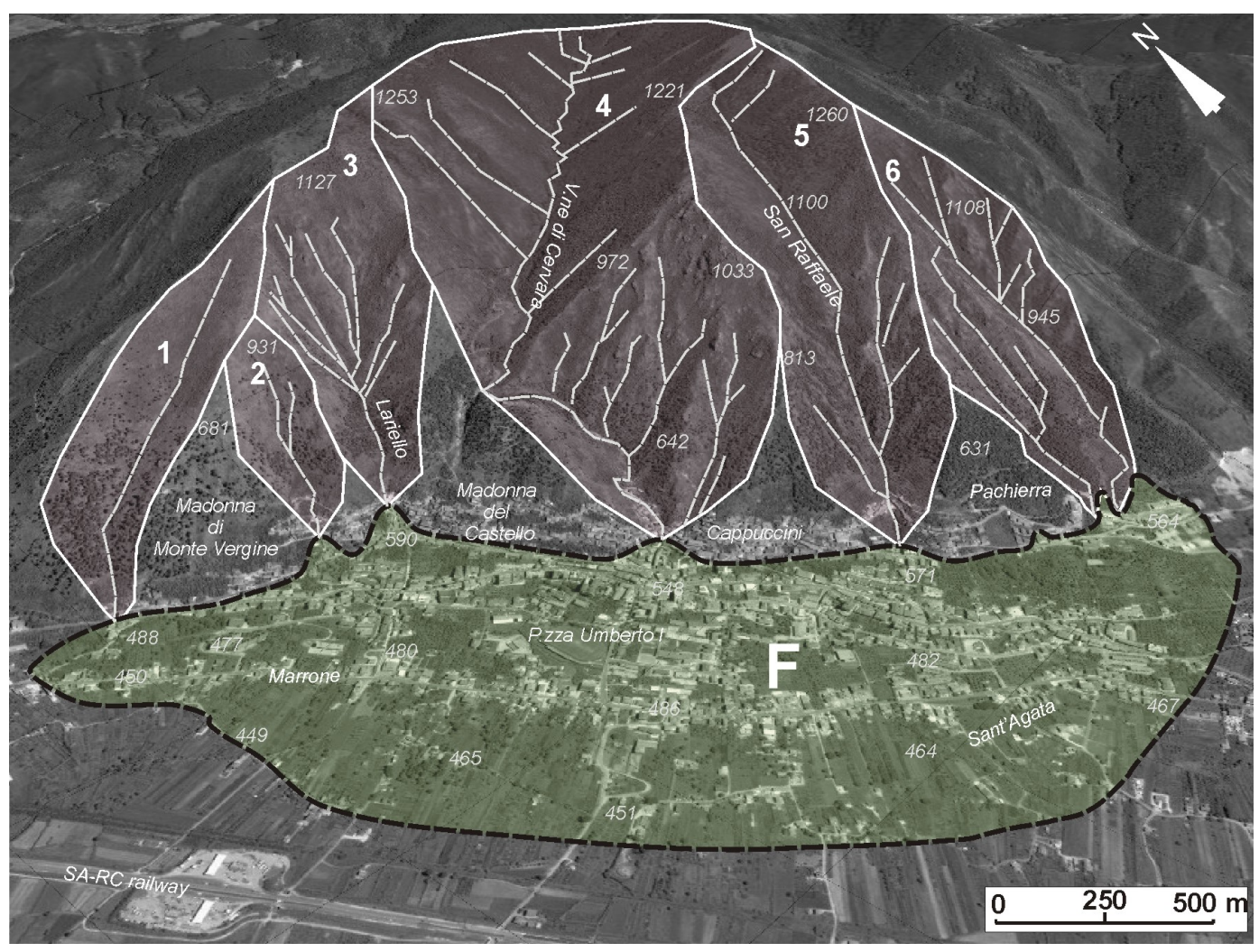

Fig. 2. Frontal view of the Sala Consilina area. (1-6) Watershed basins; (F) coalescing alluvial fans.

(1:2000). Archival research entailed consulting all the available documents at the Salerno National Archive. In particular, all the files regarding the town of Sala Consilina for the period 1806-1860 were examined. Each file consisted of correspondence between the local municipality and the general administration, with the aim of asking for funds to redress the damage. For the remaining period mainly oral and photographic evidence or newspaper data were collected. The research was accompanied by in-depth analysis of the urban toponomy during the 18th century (Spinelli, 1983), which allowed the flood-affected areas to be exactly located and a historical events map to be drawn up.

Finally, all the information on previous alluvial events and the current conditions in the catchments and fan areas helped define, by means of a map overlay procedure, the main result of this study: drawing up a susceptibility map that plots potential zones of future inundation or deposition.

\section{Results}

\subsection{Geomorphological analysis}

An initial attempt was made to describe river catchments and their respective fans based on their main morphometric parameters (Table 1). With the exception of watershed 4, which is the widest and longest and has the lowest mean slope, the areas of the basins in question are $10^{-1} \mathrm{~km}^{2}$ and mean gradients around $30^{\circ}$. The main stream is quite short, around $1 \mathrm{~km}$ with a mean gradient ranging from $16^{\circ}$ to $33^{\circ}$. More significant are the longitudinal cross sections (Fig. 3) which generally show a convex shape in the headwaters zone and have terminal segments with quite high gradients ranging from $20^{\circ}$ to $30^{\circ}$. The only exception is that of basin 4 which presents an upper and middle section with relatively low gradients and records a slope increase only in the terminal sector. In any case, according to the literature (Van Dine, 1985; Kellerhals and Church, 1990) these values are compatible with those required for debris flow initiation and propagation (at least $15^{\circ}$, but more commonly $25^{\circ}$ ).

Morphometric data also allowed some parameters to be determined (Melton index and response time) which are helpful to better characterize the watershed basins.

The Melton index, is expressed by (Melton, 1965):

$$
R=A_{\mathrm{b}}^{-0,5} \times\left(Q_{\mathrm{b}} \max -Q_{\mathrm{b}} \min \right)
$$

where ( $\left.Q_{\mathrm{b}} \max -\mathrm{Q}_{\mathrm{b}} \min \right)$ is the basin relief and $A_{\mathrm{b}}$ is the basin area.

Melton (1965) found that the fan gradient depends not only on clast size but also on the dimension and relief energy 


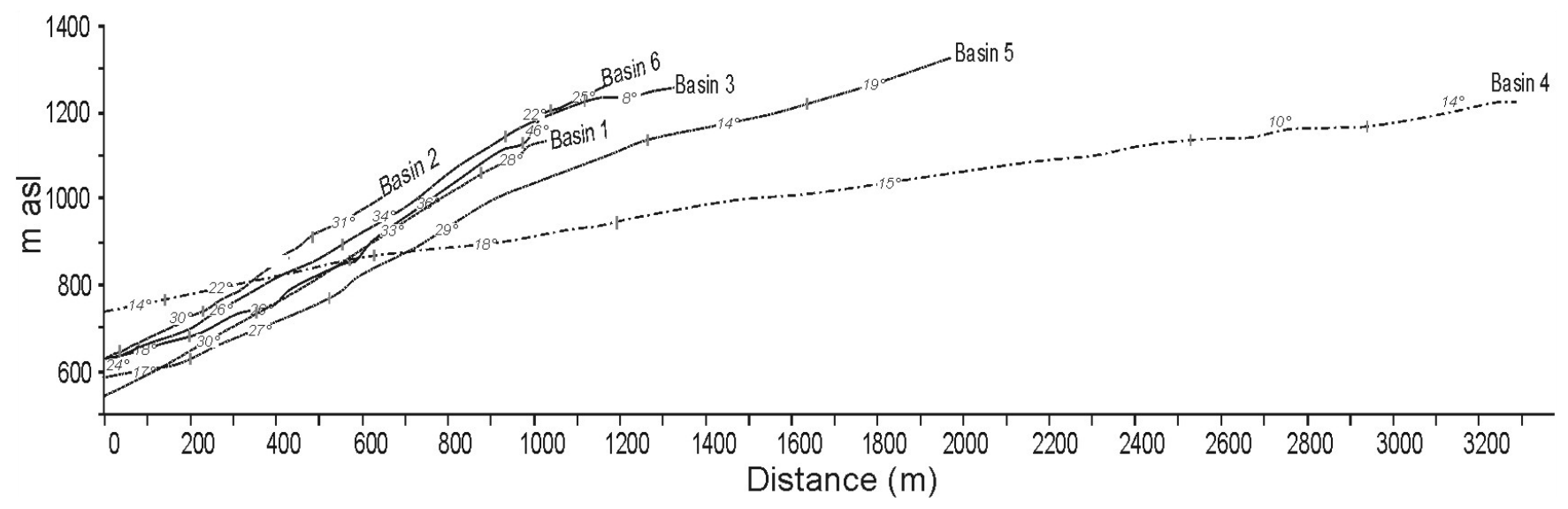

Fig. 3. Longitudinal cross profiles and main gradients of the six streams studied.

Table 1. Main morphometric parameters of the watershed basins and of the fans.

\begin{tabular}{|c|c|c|c|c|c|c|c|c|c|c|}
\hline $\begin{array}{c}\text { WATERSHED } \\
\text { BASIN }\end{array}$ & $\begin{array}{c}\text { Watershed } \\
\text { Area } \\
A_{\mathrm{b}}\left(\mathrm{km}^{2}\right)\end{array}$ & $\begin{array}{c}\text { Maximum } \\
\text { elevation } \\
Q_{\max }(\mathrm{m})\end{array}$ & $\begin{array}{l}\text { Minimum } \\
\text { elevation } \\
Q_{\min }(\mathrm{m})\end{array}$ & $\begin{array}{c}\text { Mean } \\
\text { elevation } \\
Q_{\text {med }}(\mathrm{m})\end{array}$ & $\begin{array}{c}\text { Length of } \\
\text { feeder channel } \\
L_{\mathrm{p}}(\mathrm{m})\end{array}$ & $\begin{array}{c}\text { Melton } \\
\text { Index } \\
(R)\end{array}$ & $\begin{array}{l}\text { Time of } \\
\text { response } \\
T_{\mathrm{c}} \text { (min.) }\end{array}$ & ALLUVIL & $\begin{array}{l}\text { Alluvial } \\
\text { fan area } \\
A_{\mathrm{c}}\left(\mathrm{km}^{2}\right)\end{array}$ & $\begin{array}{c}\text { Mean } \\
\text { gradient of } \\
\text { alluvial fan } J_{\mathrm{c}}\left({ }^{\circ}\right)\end{array}$ \\
\hline 1 & 0.21 & 1133 & 534 & 840 & 1025 & 1.6 & 4.3 & 1 & 0.03 & 17 \\
\hline 2 & 0.09 & 1038 & 583 & 786 & 632 & 1.5 & 3.9 & 2 & 0.05 & 9 \\
\hline 3 & 0.43 & 1284 & 620 & 995 & 1227 & 1 & 5.1 & 3 & 0.40 & 9 \\
\hline 4 & 2.66 & 1465 & 583 & 1140 & 3302 & 0.5 & 12.9 & 4 & 0.65 & 7 \\
\hline 5 & 0.84 & 1466 & 578 & 1075 & 1908 & 0.9 & 7.6 & 5 & 0.22 & 10 \\
\hline 6 & 0.51 & 1329 & 616 & 909 & 1160 & 1 & 4.9 & 6 & 0.37 & 10 \\
\hline
\end{tabular}

of the upslope stream basin. The author showed that debrisflow-dominated alluvial fans are associated with small and high-relief energy basins, and proposed a morphometric adimensional index (the Melton Index), expressing the ruggedness of the basin, aimed at classifying fans according to the characteristics of the upslope stream basin.

This index has been used by several authors (Jackson, 1987; De Scally and Owens, 2004; Pasuto et al., 1992; Marchi et al., 1993; Welsh and Davies, 2010) in other humid climate contexts to propose different threshold values for discriminating among stream-flow, mixed or debris-flow dominated alluvial fans. Despite the range of variability of this parameter, depending on the actual difference in the lithological and geomorphological contexts, it is important to stress that the studied basin/fan systems have high Melton index values, close to 1 and always greater than 0.45 (Table 1), which suggests the possibility of debris flow occurring. The response time $\left(T_{\mathrm{c}}\right)$ of the watershed basins (time required for a peak flow discharge to propagate from the headwater to the closure section) was calculated by applying the following formula (Ferro, 2006):
$T_{\mathrm{c}}=0.02221 \times(L / \sqrt{i L})^{0.8}$

where $L$ is the length of the feeder channel and $i$ is its gradient (Table 1). The results clearly show that the response time for all the studied basins is always very low, with maximum value lower than $15 \mathrm{~min}$.

Due to the high degree of urban development, the geomorphologic analysis of the fan surface was integrated with DEM elaboration, which allowed the construction of a detailed steepness map (Fig. 4). Basing identification on the detection of contour line anomalies and pronounced convexities on the fan surface, several depositional lobes were identified and reported in the geomorphologic map (Fig. 5). Some of these lobe (fans 3,4 , and 6) elongate up to $1 \mathrm{~km}$ from the apex to the distal part of the fans. At the same time, our analysis highlighted the presence of concave zones on the fan surfaces, which may represent the potential drainage lines where water overflow may occur or where debris or mud flow may be channelled. The steepness map also showed that the fan gradients are not constant. It highlighted at least three main gradient zones with values ranging from $30^{\circ}$ to $12^{\circ}$ in the apex, from $12^{\circ}$ to $6^{\circ}$ in the middle, and lower than $6^{\circ}$ in the distal sectors. These gradient variations can significantly influence the flow propagation during an alluvial event. 


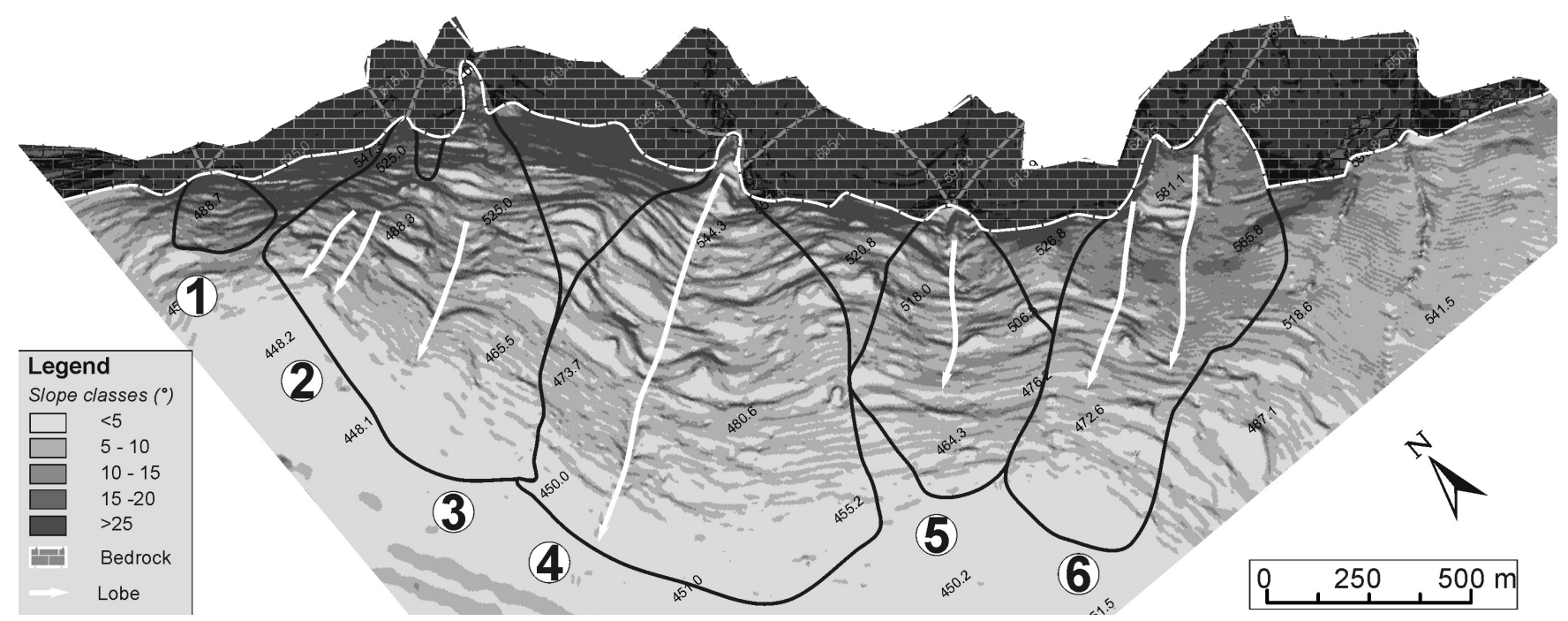

Fig. 4. Steepness map of the piedmont area.

\subsection{Field surveys and fan stratigraphy}

A second approach was included in field surveys and air photo interpretation which generated other useful geomorphological and geological data both for the watershed basins and the fans.

In the watershed zone, taking into account the land use, the cropping out lithologies, and the associated geomorphological context, five different geomorphological units were detected (Fig. 5a). The main aim of this step was to characterize the basins in terms of potential sources of debris load. All the basins are made up of Triassic dolostones which are often highly fractured, generally cropping out along the main divide (unit 1) or in coincidence of more or less wide rocky scarps which can be considered highly susceptible to falls (unit 2, Fig. 6a). Along the north-facing slopes the dolostones show a weathering horizon up to $50-100 \mathrm{~cm}$ thick which sustains a well developed forest cover. These slopes generally show a high gradient and are mainly affected by gully erosion processes but may also be interested by local failures of the soil cover (unit 3). The remaining slopes, which also have high gradients, are more irregular and have pronounced concave zones filled in by talus deposits. The latter are made up by a sandy-silty matrix-supported breccia (Fig. 6b), which generally has a thickness of 50-100 cm and sustains a shrub land and grassland vegetal cover. Within this geomorphological unit (unit 4), the main active erosion processes are represented by debris slides and rill and gully erosion. Finally, the last geomorphological unit (unit 5) is located in coincidence with the main streambeds which are filled in by very coarse alluvial deposits up to $1-2 \mathrm{~m}$ thick, merging laterally with slope breccias. In this zone fluvial erosion is the dominant process.
The information that we gathered suggests that these zones may be considered active with respect to erosion and may all contribute, albeit in different ways, to the increase in bed load. For example, the sandy-silty superficial deposits which characterise unit 4 may affect the amount of runoff during heavy short-lasting rainfall events. At the same time, diffuse (sheet wash) or concentrated (gully erosion or debris slides) erosion processes may affect these deposits, contributing to increasing the bed and suspended load of the main stream. From the frequency diagrams in Fig. $5 \mathrm{~b}$ it emerges clearly that in all the studied basins the unit 4 has a frequency included between $30 \%$ and $50 \%$, reaching the maximum value in the basin $\mathrm{n}$. 5. In the same way the basins number 2,4 , and 6 register a significant presence of unit 5 , which is characterized by alluvial deposits that can be taken in charge by the main stream during flood events. Finally, the unit 3, which may contribute to bed load increase by means of local slides of the soil cover, is more abundant in the basins number 4 and 5. By considering the total area of the basins which is $4.74 \mathrm{~km}^{2}$, it is important to outline that the sum of the geomorphological units (units $3,4,5$ ) that may be significant as sources of bed load (Fig. $5 \mathrm{c}$ ) reaches a value of $3.17 \mathrm{~km}^{2}$. Moreover, it can be stressed that the basin n. 4, representing $64 \%$ of the total erodible area may be considered as the most productive.

As regards the field survey in the fan zone, despite the generally flat topography and the high degree of urbanization, several exposures were detected. They are generally located near road cuts, channel banks, and other excavations, and in some cases (Fig. 5a) are found in coincidence with depositional lobes detected through geomorphological analysis. Exposures observation allowed the description of the more superficial portion (depth between 3 and $10 \mathrm{~m}$ ) of the stratigraphic record. Although the deposits are generally poorly stratified, different depositional events separated by erosion 


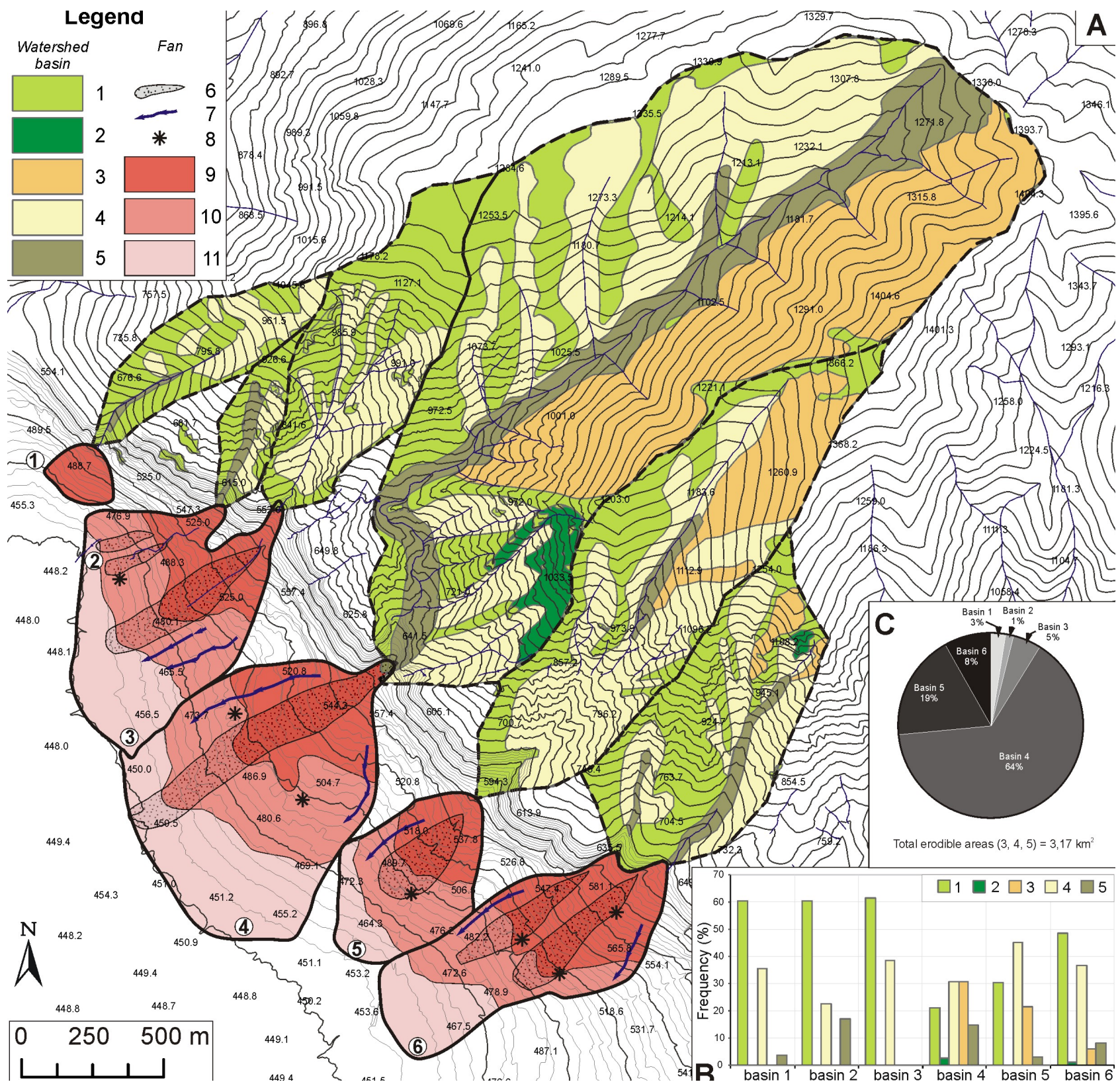

Fig. 5. (A) Geological and geomorphological map of the basin-fan systems. Watershed zone: 1) main divides with absence of vegetation (unit 1); (2) rocky cliffs (unit 2) ; (3) regular, high gradient slopes with continuous forest cover (unit 3); (4) irregular high gradient slopes with brushland or grassland cover (unit 4); (5) main streambeds (unit 5). Fan zone: (6) recent lobe; (7) concave zone; (8) main stratigraphic exposure; steepness classes (9) $30^{\circ}-12^{\circ}$; (10) $12^{\circ}-6^{\circ}$; (11) lower than $6^{\circ}$. (B) Geomorphological units distribution within the studied basins. (C) Extent of erodible areas in the studied basins.

surfaces can be detected (Fig. 7). The more representative lithofacies is made up of a clast-rich, carbonate gravel that is massive, matrix-supported, and poorly sorted. Some clasts attain boulder size (maximum length from $50 \mathrm{~cm}$ to $1 \mathrm{~m}$ ) and vary in shape from angular to sub angular (Fig. 7c and d). The matrix is commonly composed of carbonate sand and/or of reworked palaeosols. The uppermost levels are often made of massive silty sands containing coarse (medium length;
20-30 cm), sub-angular bedrock clasts and, in some cases (Fig. 7b), remains of ancient pottery (Roman and/or Medieval), which testify to the historical age of the upper portion of the fans. In other cases the youngest depositional lobes have clearly surrounded the walls of 17 th century buildings (Fig. 7e and f).

Overall, the absence of sedimentary structures, the poor sorting, and the matrix-supported texture can be attributed 

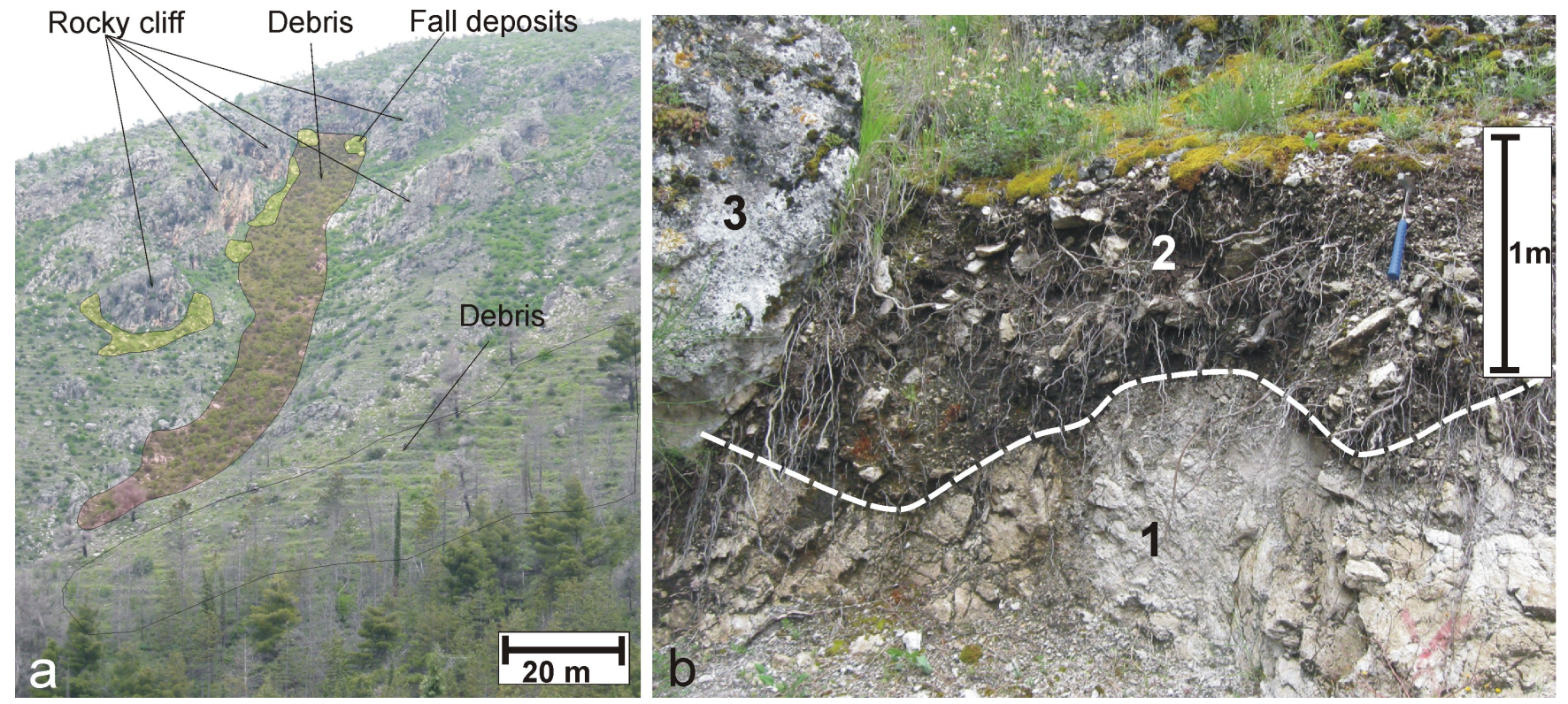

Fig. 6. Example of some geomorphological and lithological units characterizing the watershed basins. (a) Rocky cliff susceptible to fall phenomena (unit 2). (b) Detail of the superficial deposits characterizing unit 4: very fractured dolostones (1) covered by silt-sandy matrixsupported breccia (2); and rock fall boulder (3).

to rapid accumulation under fast-moving, heavily sedimentladen turbulent flows, thus suggesting the prevalence in fan building of debris-flow dominated sedimentary processes.

\subsection{Mapping roads and hydraulic network conditions}

The field survey also aimed to highlight how urban expansion modified the natural drainage lines in the fan areas. To this aim the main hydraulic works, the streets covering or replacing the real stream beds, and the critical points where overflows may occur were accurately mapped (Fig. 8).

In almost the whole apical zone of the studied fans, the feeding stream has been forced to flow underground and is covered by a street (Fig. 9a and b). Moving down-valley the stream re-emerges but in many cases the cross-section is very small and the bed is completely surrounded by buildings (Fig. 9c and d). Weirs are sometimes present but unfortunately they are generally filled in with any kind of material (coarse debris, vegetation, rubbish), showing a very poor degree of maintenance. All the information concerning the different conditions of the feeder channel (natural, artificial, buried, etc.) were accurately gathered during the field survey and reported in the map (Fig. 8).

In addition, many streets develop along the main gradient of the fan surface and in many cases they are located in coincidence with ancient depositional lobes. In this sense, they were considered potential preferential pathways for flow propagation in the event of flooding. At the same time we mapped the most critical points, such as narrowing cross sections and abrupt drainage deflection.

\subsection{Historical analysis}

By means of the historical analysis, nine major alluvial events were detected from 1806 to 1947 (Table 2), and the main flood-affected areas were exactly located on the relative map (Fig. 10).

A careful reading of records provided a description of the events, upon which the event type could be hypothesized. The oldest and best documented event occurred on 9 June 1806 (Archivio di Stato, 1806a, b) when: " the waters draining into Mr Petrini's property (present-day Via De Petrinisi, fan 4) brought with them an infinity of big stones which banged into the houses, made 40 of them collapse, killed 30 people and injured more than 50".

A few years later, on 4 and 19 December 1814, severe thunderstorms affected Sala Consilina (Archivio di Stato, 1814, 1815), blocking the residents of La Valle and S. Giovanni districts (fans 2, 4, and 5) inside their houses because the streets were impassable. The reports refer that: "Very large rock masses and sand obstructed the Santa Maria del Monte streets" (present-day Via Vairo, Marroncelli, and Poerio).

On 6 June 1822 (Archivio di Stato, 1822), the urban area of Sala Consilina (Piazza Monteoliveto and the De Petrinis estate, fan 4) was invaded by "considerable deposits of stones, rubble and sand". The doors to many houses and shops were blocked and the owners had to move the debris before entering them again.

A very serious alluvial event occurred on 13 June 1858 (Archivio di Stato, 1858a, b, c, d): the waters carried 

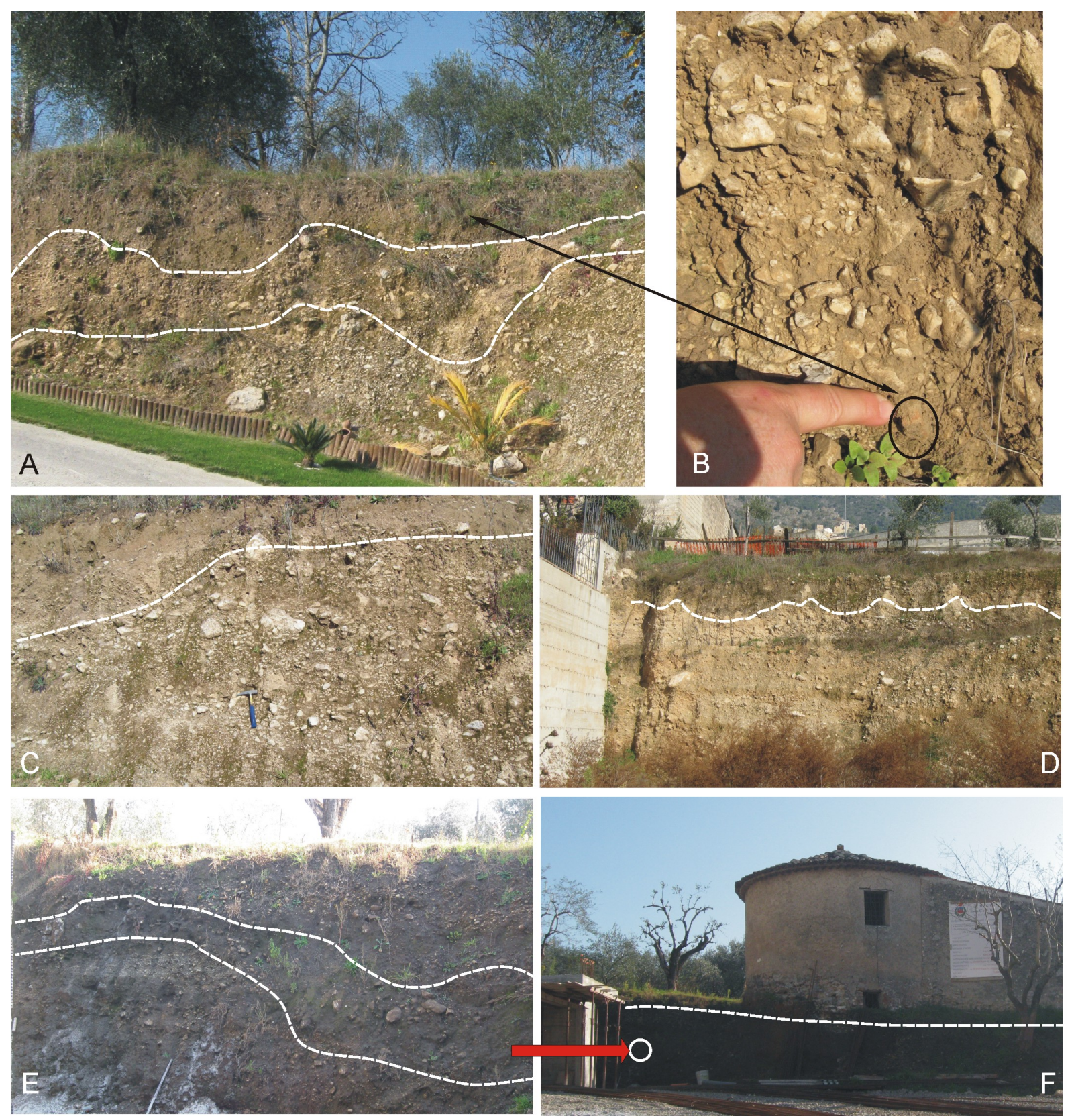

Fig. 7. Details of the fan deposits. (A, C, D): poorly stratified calcareous conglomerates separated by erosion surfaces. (B): the uppermost levels sometimes contain remains of Roman pottery. (E) and (F): wall of an ancient building surrounded by fan deposits showing a debris flow facies.

"immeasurable rocks" which caused 50 buildings to collapse, the death of 22 people and severe damage to rural zones in the S. Eustachio district (present-day Via Indipendenza, Vairo, A. Da Brescia, U. Bossi, and C. Battista, fans 2).

As regards photographic testimony is concerned, particularly significant are those for November 1927 and June 1947 (Fig. 11a, b, c). Many streets and Piazza Umberto I (fan 4) were partly or completely invaded by deposits which caused serious damage to buildings and resulted in extensive loss of life.
All these descriptions have several points in common, namely:

- street obstruction by large quantities of debris deposits;

- large size of boulders carried out by the flow and associated presence of finer materials;

- breakdown of buildings with victims.

Based on this observation we were able to hypothesize that in the majority of the cases (Table 2) the alluvial events 


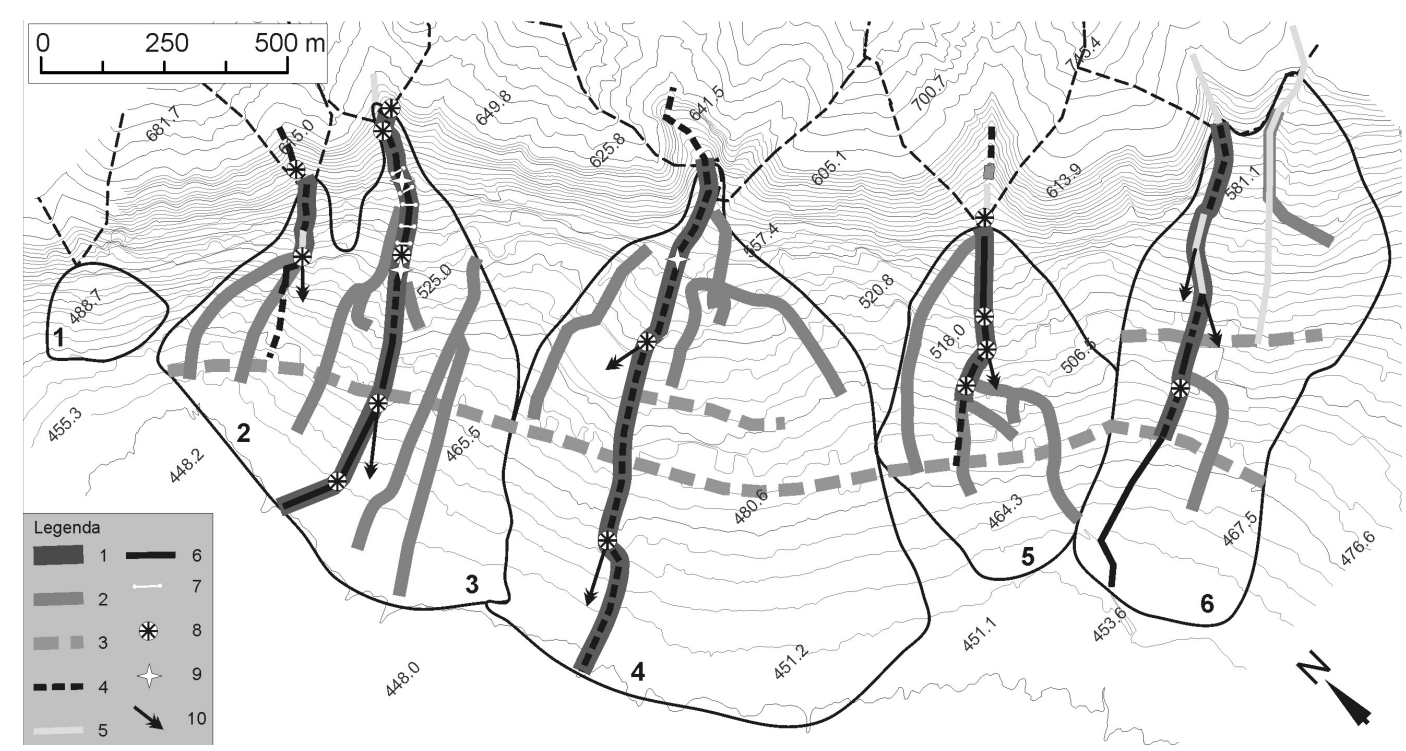

Fig. 8. Map of the hydraulic network condition. (1) Main road along which the flow can be easily channelled; (2) secondary road along which the flow can be channelled; (3) street perpendicular to the fan direction where the flow can't be channelled; (4) underground channelled stream. (5) natural streambed; (6) stream bed transformed into road; (7) weir; (8) critical point due to the abrupt change in stream direction; 9) critical point due to the small cross section of the stream; (10) possible outflow direction.

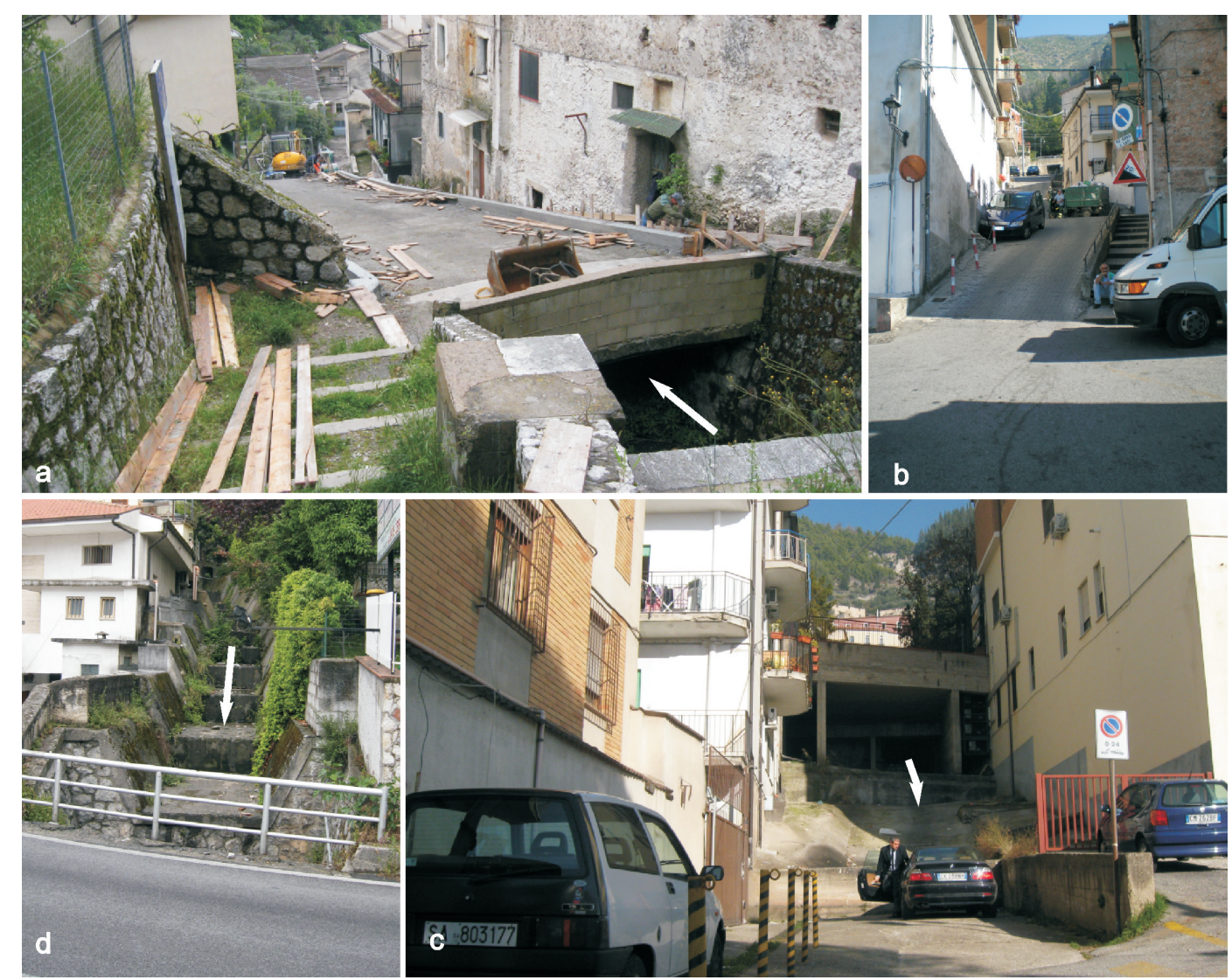

Fig. 9. Examples of hydraulic critical points in Sala Consilina: (a) and (b) the main stream is channelled underground; (c) the stream re-emerges but its bed has become a road; (d) the stream has a very small cross-section and is completely surrounded by houses. 
Table 2. List of the historical events and damages occurred at Sala Consilina from 1806 to 1947. The capital letters in the third column refer to Fig. 10.

\begin{tabular}{|c|c|c|c|}
\hline Flood event & Sites affected by the flood & Loc. & Damages and victimes \\
\hline 4 December 1814 & $\begin{array}{l}\text { LaValle; Costantino Gatta, S. Giovanni Camera } \\
\text { streets and surroundings }\end{array}$ & $\mathrm{B} / \mathrm{C}$ & Damages to roads \\
\hline 19 December 1814 & Vairo, Marroncelli, and Poerio streets & $\mathrm{D}$ & Damages to roads \\
\hline January 1815 & Ruderi, Castello, and V Campanella streets & $\mathrm{E}$ & Damages to roads and collapsed walls \\
\hline 6 June 1822 & Piazza Umberto I, Via De Petrinis e dintorni & $\mathrm{F}$ & Many deposits on the roads \\
\hline November 1927 & Umberto I square and surroundings & $\mathrm{F}$ & Many victimes and damages to homes and roads \\
\hline June 1947 & Umberto I square and surroundings & $\mathrm{F}$ & Many victimes and damages to homes and roads \\
\hline
\end{tabular}

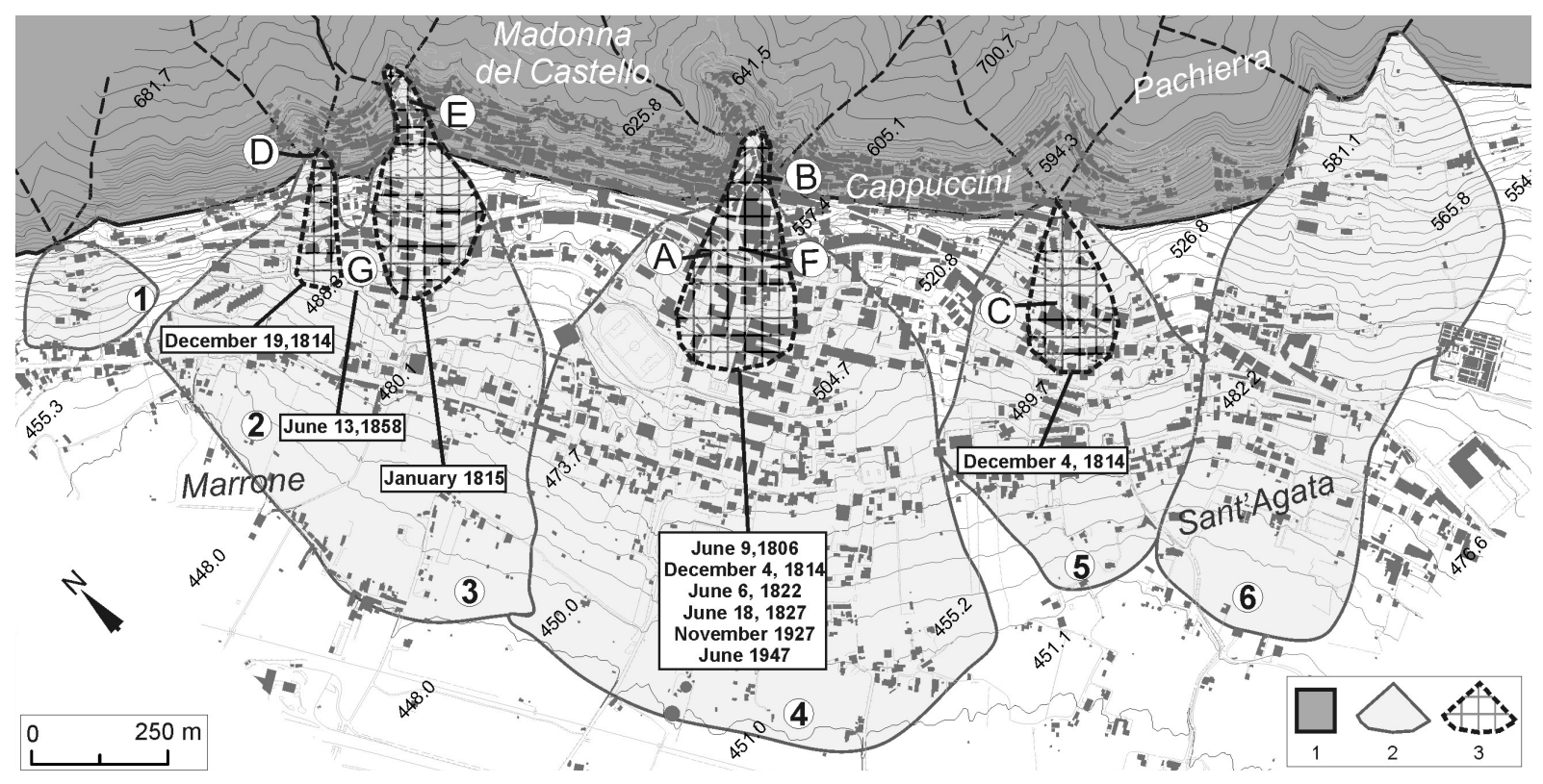

Fig. 10. Historical events map (1) border slope; (2) alluvial fan; (3) damage zone. The letters refer to localities cited in Table 2.

involved debris flow processes. Moreover, the historical data also suggest that the areas more severely hit by the alluvial events are those of Piazza Umberto I and the adjacent streets (fan n. 4). Rough evaluation of the volume involved during these events can be deduced from the 1947 photos. Given the minimum thickness (at least $50 \mathrm{~cm}$ ) of the deposits which accumulated at Piazza Umberto I, the width of the street, and the distance from the fan apex, the volume in question can be estimated at some thousands of cubic meters.

Importantly, the extent of the damage inferred for the period 1806-1947 is obviously greatly influenced by the size of the town during the period in question, which was smaller than at present. By comparing topographic maps of different ages $(1871 ; 1989 ; 1954 ; 2004)$, we reconstructed the expansion of the town (Fig. 12). The map clearly shows that the greatest expansion occurred after 1960 and especially in the last $20 \mathrm{yr}$. In the figure, resident population data and the corresponding urban area $\left(\mathrm{km}^{2}\right)$ from 1871 up to 2009 are also shown. Clearly, urban expansion has occurred in all directions without taking into account the presence of streams and/or depositional lobes. Moreover, the number of residents has increased from 8181 to 12732 . These data suggest that if events like those occurring during the 19th century were repeated today, the extent of damage could be very much greater. 

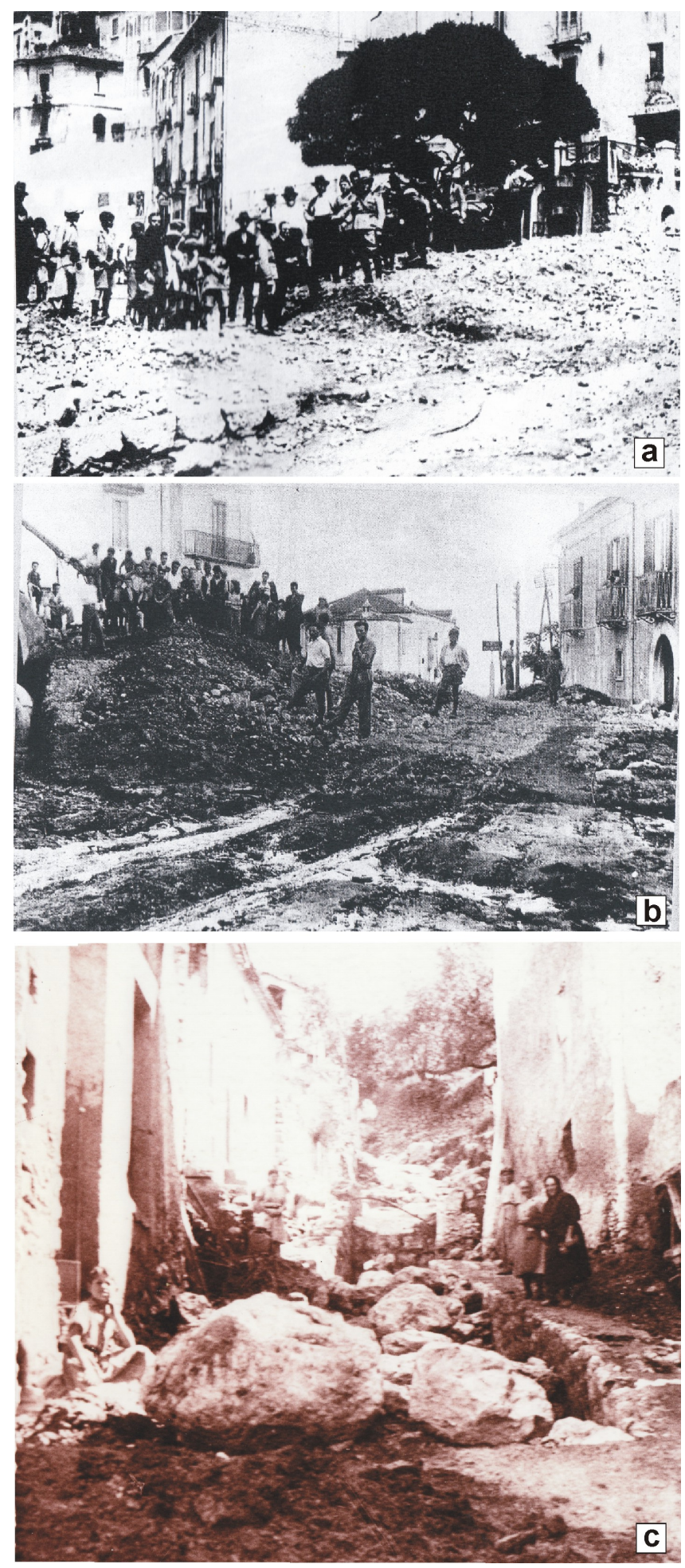

Fig. 11. Historical pictures of the events occurring during the 20th century (A) 1927 event: damage in Piazza Umberto I (fan 4); (B) and (C) 1947 event: streets near Piazza Umberto I (fan 4).
In conclusion, historical analysis makes it possible to recognize the occurrence in recent centuries at Sala Consilina of several alluvial events, some of which were characterized by debris flow processes. Unfortunately, it was impossible to establish the actual rainfall intensity associated with each event because the only rain gauge located in the study area started its records in 1930, mainly with daily values; only in some cases are hourly rainfall records available. Moreover, in the period 1931-1951 the data are largely discontinuous. For the last $60 \mathrm{yr}$ the rainfall data are more reliable but the rain gauge is located at low altitude and at long distances from the areas where the floods occurred. Hence, the recorded values do not express the real rainfall occurring and cannot be used to define threshold values or to reconstruct the return time of the alluvial events.

\subsection{Alluvial fan flooding susceptibility}

The information gathered in the course of our research was needed to depict possible future flood scenarios. Geomorphological and stratigraphic analysis showed that the studied basin/fan systems are active and can be considered prone both to flooding and debris-flow propagation. At the same time, the study allowed the location of the main erosion and deposition zones within the whole piedmont area. Comparing these data with those from historical analysis and from the survey of the hydraulic network, it was possible to reconstruct a fan flooding susceptibility map (Fig. 13). The map was constructed by means of a map overlay procedure (ArcGis application) based on a susceptibility matrix which takes into account the main steepness classes and links them with the other natural and artificial predisposing factors. In particular, the three classes of steepness data were linked with the presence of ancient depositional lobes, with the presence of artificial anomalies on the fan surface (street orientation, stream deflection, critical points) and with the occurrence of historical events. To each slope class an increasing score from 1 to 3 was assigned and thus the first three zones with different susceptibility were detected. The other three aggravating parameters were then considered, each with a score equal to 1 . Based on their presence/absence, three other levels (ranging from 1 to 3 ) of scores may be defined. The following layers crossing allow four different susceptibility classes to be detected.

The very high susceptibility zones (score from 5 to 6 ) are characterized by the highest gradient; they are generally located in the fan apex or where all the predisposing factors are present. Historical data suggest that they can be considered as the direct impact zone in the event of debris flows. Materials transported through these zones could include boulders up to about one meter in diameter, tree trunks, coarse debris which can produce great damage and the obstruction of the main hydraulic channel if the stream was forced to flow underground. If an ancient lobe or main streets are present, 


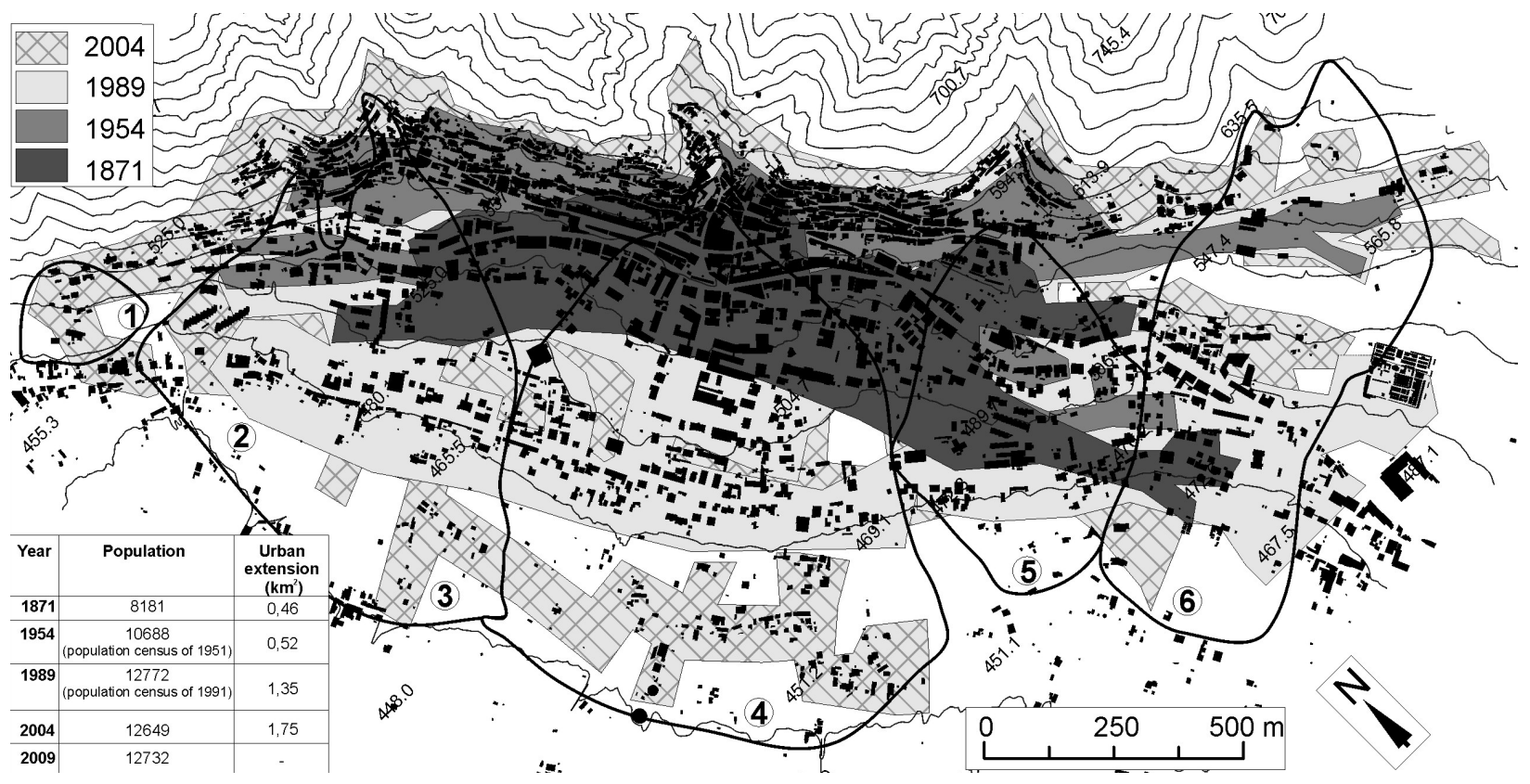

Fig. 12. Urban growth of Sala Consilina from 1871 to 2004.

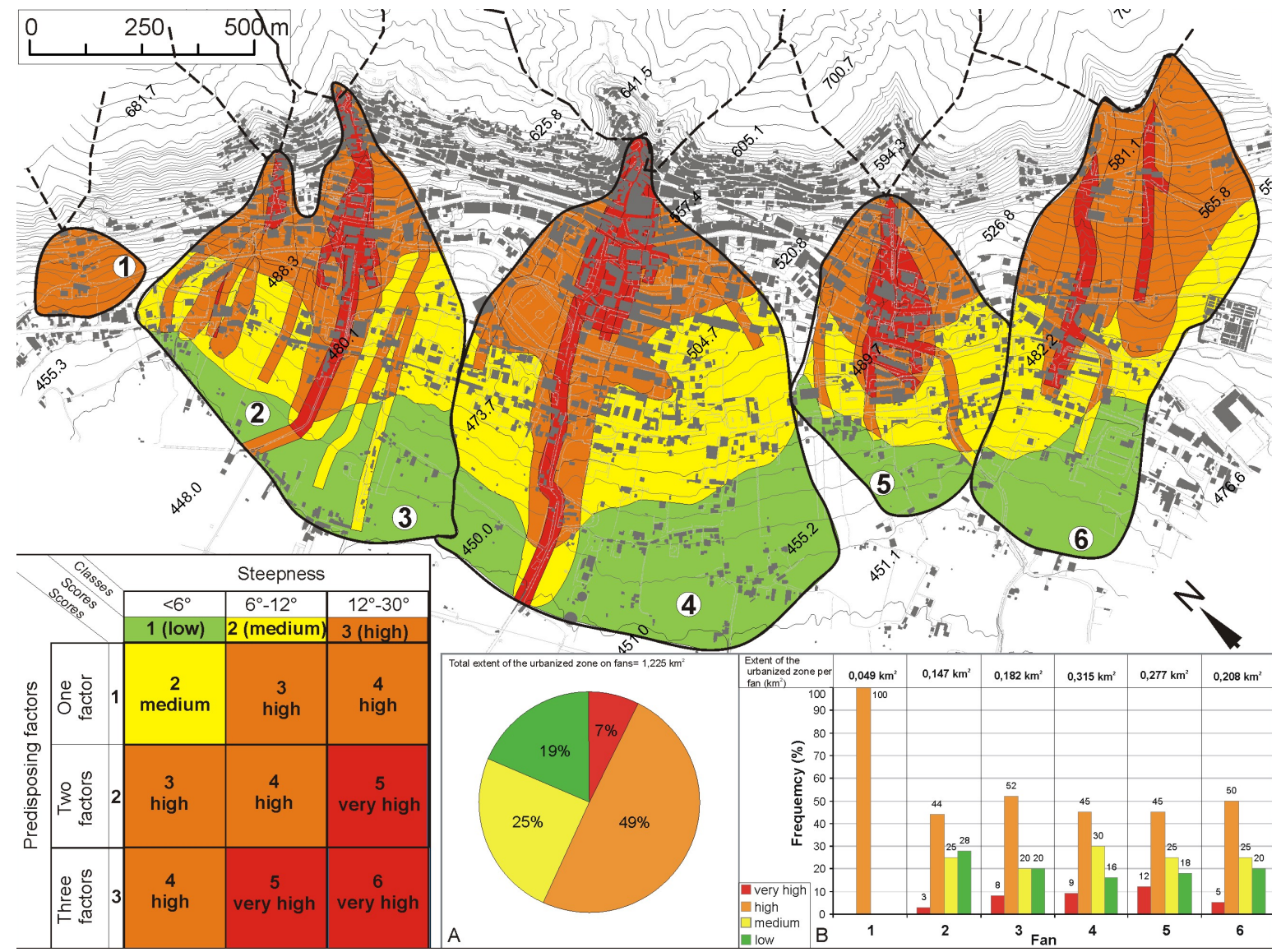

Fig. 13. Alluvial fan flooding susceptibility map. 
along which the flow may be easily channelled, these zones extend down-fan reaching the most distal part.

The high susceptibility zones (scores from 3 to 4 ) are those where the flows may be diverted and/or through which afterflow may travel. Their distribution is strongly influenced by the presence and orientation of the main streets and buildings. Material may include rock and debris but is more likely to contain boulders less than $0.5 \mathrm{~m}$ in diameter to fine grained material. The potential damage is strictly linked to the water discharge and its velocity.

The medium susceptibility zones (a score of 2 ) are located in the middle fan area and may be affected by the distal or lateral portion of flows carrying finer materials. Flooding of the buildings base level floor and low water level (some $\mathrm{dm}$ ) along the street may be expected.

Finally, the low susceptibility zones (a score of 1) are those with low gradients, located in the distal part of the fans where the other negative predisposing factors are absent. They are exposed only to flooding; sizable damage is not expected since the water level (several $\mathrm{cm}$ ) will probably be low and only fine-grained material and mud may be contained in the flood water.

At this point some further considerations on the potential magnitude of the events can be made by considering the data related to the sedimentary supply in each watershed basin, exposed in Sect. 5.1. In fact it can be stressed that even if all the basins may be interested by high bed load transport, portions of different fans with equal susceptibility conditions may be subject to alluvial events with different intensity (in terms of volume of sedimentary load). In particular, the data gathered for the watershed basins n. 4, 5, and 6, which have resulted as the most productive in terms of debris source (Fig. 5c), suggest the possible occurrence within these basins of higher magnitude events.

The interaction between the urban area and the previously defined more or less susceptible zones (Fig. 13a) clearly shows that $70 \%\left(1.225 \mathrm{~km}^{2}\right)$ of the urban area is located within the alluvial fan zone and that $7 \%\left(0.091 \mathrm{~km}^{2}\right)$ and $49 \%\left(0.604 \mathrm{~km}^{2}\right)$ of this value belong, respectively, to very high and high susceptibility classes. If we consider the single fan (Fig. 13b), more than $50 \%$ of the urban area located in each system shows high and very high susceptibility conditions. Moreover, the fan number 4 , followed by the basins 5 and 6 , have the greatest extent of urbanized area $(0.315$, 0.277 and $0.208 \mathrm{~km}^{2}$, respectively).

\section{Discussion}

From the information which we gathered it emerges that the Sala Consilina fans are prone to debris flow phenomena and that in the past (1806-1947) these processes have produced severe damage and loss of life in the urban area. Importantly, the historical sources in some cases provided the description of the flood, indicating its concomitance with concentrated rainfall or with exceptional events. It was unfortunately impossible to establish the actual rainfall intensity because the only rain gauge located in the study areas started its records in 1930, mainly with daily values, and in the period 19311951 the data are greatly discontinuous.

The studied basins belong to the category of small catchments, i.e. basins less than a few $\mathrm{km}^{2}$ with a response time shorter than $1 \mathrm{~h}$. Such basins are generally very sensitive to rainfall events like flash floods (Ruin et al., 2008) which in recent years have become increasingly frequent in the Mediterranean environment (Norbiato et al., 2007, 2008, 2009; De Waele et al., 2010). Hazard conditions will therefore increase if the Mediterranean climate registers an increasing frequency of very short, intense thunderstorms, as portrayed by the recent international report on climate change (IPCC, 2007) and papers documenting a general increase in flood frequency with raising concentration of anthropogenic greenhouses gases and associated air temperature increase (Allan, 2011; Schiermeier, 2011).

Within this general view, the collected historical record, though not homogeneous and influenced by many external factors (different degrees of urbanization, absence of data for the II World War period, etc.), may represent a good ana$\log$ for the future floods in terms of severeness and potential damage. During the 19th century, in fact, the recurrence of the main rainfall events which caused significant flooding events was shorter (twenty years) than in the 20th century. This is probably due to the particular climatic conditions at the time: according to Diodato (2007), in southern Italy the period between 1798 and 1919 was characterized by very wet conditions, with higher flooding frequency.

\section{Conclusions}

The great urban expansion which has occurred in the foothill areas of southern Italy in recent decades makes the problem of defining flooding susceptibility increasingly urgent. In such contexts the difficulty in carrying out investigations and the lack of data or field evidence of past debris flows cause real problems in producing detailed and exhaustive studies. Risk management planning is generally tackled by local administrations (such as watershed basin authorities) in an approximate way and at an inadequate scale (1:25000 or $1: 10000)$.

The procedure described in this paper allows flooding susceptibility zoning at a very detailed scale $(1: 2000)$. It is based on a painstaking field survey both in the watershed basin and in the fan areas, associated with in-depth historical research of past events. Taking into account historical damage, the fan surface gradient, and the present urban development (street orientation and hydraulic channel network), the piedmont area was zoned and four different susceptibility classes were established. The zones are subject to different processes and may thus be affected by events of different 
magnitudes. Debris flow events are more likely to impact in the apical zone of the fans and may travel only along the steepest zone, following the main gradient direction. Mud flows and floodwaters may travel through the apex and propagate in the down-valley sector of the fans. Indeed, extensive parts of the urbanized area belong to very high and high susceptibility classes, thus suggesting the presence of real risk conditions. Although it was not possible to calculate the return time exactly and hence the probability of such events occurring, the historical data suggested that the reconstructed scenarios may occur within a $100 \mathrm{yr}$ time span.

The reconstructed flooding scenarios, showing the fan portions potentially affected by different alluvial processes, may represent a useful tool for subsequent, quantitative, hydraulic studies aimed at land hazard and risk mapping. In particular, the proposed procedure, allowing precise susceptibility zoning within an urbanized area, may contribute significantly to defining intervention priorities and planning risk mitigation works.

Acknowledgements. The Authors wish to thank the Editor (Fabio Luino), the reviewers (Marino Sorriso Valvo and an anonymous referee) for the useful suggestions.

Edited by: F. Luino

Reviewed by: N. Nadal and another anonymous referee

\section{References}

Apat: available at: http://www.apat.gov.it/media/carta_geologica_ italia/tavoletta.asp?foglio=199, 2011.

Aleotti, P. and Chowdhury, R.: Landslide hazard assessment: summary review and new perspectives, Bull. Eng. Geol. Env., 58, 21-44, 1999.

Allan, P. R.: Human influence on rainfall, Nature, 470, 344-345, 2011.

Ascione, A., Cinque, A., Santangelo, N., and Tozzi, M.: Il bacino del Vallo di Diano e la tettonica trascorrente plio-quaternaria: nuovi vincoli cronologici e cinematica, Studi Geol. Camerti, 1992/1, 201-208, 1992.

Archivio di Stato di Salerno: Memoria presentata dai Deputati di Sala al sovrano Giuseppe Napoleone ed inoltrata al Ministero dell'Interno, Intendenza, Opere Pubbliche Comunali, b. 1271 f.2., Sala Consilina, 25 luglio 1806a.

Archivio di Stato di Salerno: Dal ministro dell'interno Miot al Preside di Salerno, Intendenza, Opere Pubbliche Comunali, b. 1271 f.2. Napoli, 25 luglio, 1806 b.

Archivio di Stato di Salerno: Dal sottointendente del distretto all'intendente. Intendenza, Opere Pubbliche Comunali, b. 1271 f.19. Sala, 14 dicembre, 1814.

Archivio di Stato di Salerno: Dal sottointendente del distretto, il cavaliere Ferrante, all'intendente, Intendenza, Opere Pubbliche Comunali, b. 1271 f.23. Sala, 8 dicembre, 1815.

Archivio di Stato di Salerno: Dal sottointendente del distretto all'intendente, Intendenza, Opere Pubbliche Comunali, b. 1272 f.8. Sala, 29 giugno, 1822.
Archivio di Stato di Salerno: dal sottointendente del distretto all'intendente, Intendenza, Opere Pubbliche Comunali, b. 1273 f.29. Sala, 28 agosto, 1858a.

Archivio di Stato di Salerno. Dal sottointendente del distretto all'intendente, Intendenza, Opere Pubbliche Comunali, b. 1273 f.30. Sala, 13 giugno, 1858 b.

Archivio di Stato di Salerno: Dal sottointendente del distretto all'intendente, Intendenza, Opere Pubbliche Comunali, b. 1273 f.30. Sala, 14 giugno, $1858 \mathrm{c}$.

Archivio di Stato di Salerno: Dal sottointendente del distretto all'intendente. Intendenza, Opere Pubbliche Comunali, b. 1273 f.30. Sala, 15 giugno, 1858d.

Bottino, G. and Crivellari, R.: Analisi di colate detritiche connesse con l'evento alluvionale del 5-6 novembre 1994 nell'Anfiteatro Morenico di Ivrea, Atti del Convegno internazionale Rischio Idrogeologico, opere di difesa ed uso del territorio nel Cavanese, Ivrea 8-9 Maggio 1998, 35-45, 1998.

Budetta, P., Santangelo, N., and Santo, A.: Interazioni tra processi alluvionali ed insediamenti abitativi in epoca storica: il caso della Certosa di Padula, Convegno GeoBen 2000, Torino 7-9 giugno, 41-48, 2000.

Bull, W. B.: Alluvial fans, J. Geol., 16, 101-106, 1968.

Bull, W. B.: The alluvial fan environment, Prog. Phys. Geogr., 1, 222-270, 1977.

Canuti, P. and Casagli, N.: Considerazioni sulla valutazione del rischio di frana. Atti del Convegno, Fenomeni Franosi e centri abitati, Bologna 27 maggio 1994, C.N.R.-G.N.D.C.I, 846, 29-130, 1996.

Cascini, L., Bonnard, C. H., Corominas, J., Jibson, R., and Montero-Olarte, J.: Landslide hazard and risk zoning for urban planning and development. State of the Art Report (SOA7), in: Proceedings of the International Conference on "Landslide Risk Management", Vancouver (Canada), edited by: Hungr, O., Fell, R., Couture, R., and Eberthardt, E., Taylor and Francis, London, 199-235, 2005.

Castelli, M., Bonnard, C. H., Durville, J. L., Forlati, F., Poisel, R., Polino, R., Prat, P., and Scavia, C.: IMIRILAND project - Impact of Large Landslides in the Mountain Environment : Identification and Mitigation of Risk., Proc. Int. Conf. on InstabilityPlanning and Management, Isle of Wight, UK May 2002, Ed. Thomas Telford, 671-678, 2002.

D'Agostino, V.: Analisi quantitativa e qualitativa del trasporto solido torrentizio nei bacini montani del Trentino Orientale, in: Associazione Italiana di Ingegneria Agraria $1^{\circ}$ sezione, Convegno di Studio, i problemi dei grandi comprensori irrigui, Novara 6-7 giugno 1996.

De Scally, F. A. and Owens, I. F.: Morphometric controls and Geomorphic responses on fans in the Southern Alps, New Zealand, Earth Surf. Proc. Land., 29, 311-322, doi:10.1002/esp.1022, 2004.

De Waele, J., Martina, M. L. V., Sanna, L., Cabras, S., and Cossu, A.: Flash flood hydrology in karstic terrain: Flumineddu Canyon, central-east Sardinia, Geomorphology, 120, 162-173, 2010.

Diodato, N.: Climatic fluctuations in southern Italy since the17th century: reconstruction with precipitation records at Benevento, Clim. Change, 80, 411-431, 2007.

Fell, R. and Hartford, D.: Landslide risk assessment, in: Landslide risk assessment, Proceedings of the international workshop on 
landslide risk assessment, edited by: Cruden, D. and Fell, R., 51-110, 1997.

Ferro, V.: La sistemazione dei bacini idrografici, 2nd Edn., McGraw-Hill, Milano, 848 pp., 2006.

Flentje, P. N., Chowdhury, R. N., and Tobin, P.: Management of landslide triggered by a major storm event in Wallongong, Australia, Second International Congress on Debris Flows Hazard Mitigation, Taipei, Taiwan, 479-487, 2000.

Guzzetti, F., Stark, C. P. and Salvati, P.: Evaluation of Flood and Landslide Risk to the Population of Italy, Environ. Manage., 36, 15-36, 2005.

Harvey, A. M.: The role of alluvial fans in arid zone fluvial systems, in: Arid Zone Geomorphology: Process, Form and Change in Dry lands, edited by: Thomas, D. S. G., 2nd Edn., Wiley and Sons, 231-259, 1997.

Hungr, O., Evans, S. G., Bovis, M. J., and Hutchinson, J. N.: A review of the classification of landslides of the flow type, Environ Eng Geosci., 7, 221-238, 2001.

IPCC: Intergovernmental Panel on Climate Change, Fourth Assessment Report: Climate Change 2007: Synthesis Report, Core Writing Team, edited by: Pachauri, R. K. and Reisinger, A., Geneva, Switzerland, 2007.

Jackson, L. E. J. R., Kostaschuk, R. A. and Mac Donald, G. M.: Identification of debris flow hazard on alluvial fans in the Canadian Rocky Mountains, Geol. Soc. Am., Rew. Eng. Geol., 7, 115-124, 1987.

JTC-1: International guidelines for landslide susceptibility, hazard and risk zoning, Eng. Geol., 103, 85-98, 2008.

Kellerhals, R. and Church, M.: Hazard management on fans, with examples from British Columbia, in: Alluvial Fans, a field approach, edited by: Rachocki, A. H. and Chuch, M., New York, Wiley, 335-354, 1990.

Laigle, D. and Marchi, L.: Example of mud debris flow hazard assessment, using numerical models, Second International Congress on Debris Flows Hazard Mitigation, Taipei, Taiwan, 417-424, 2000.

Lee, E. M. and Jones D. K. C.: Landslide risk assessment, 404, Thomas Telford, London, 454 pp., 2004.

Leone, F., Ast'e, J. P., and Leroi, E.: Vulnerability assessment of elements exposed to mass movements: working toward a better risk perception, in: Landslides, Glissements de terrain, Proceed. VII Int. Sym. Landslides, Trondheim, edited by: Senneset, K., Rotterdam, 263-270, 1996.

Marchi, L. and Tecca, P. R.: Alluvial fans of Eastern Italian Alps: morphometry and depositional processes, Geodinamica Acta, 8, 20-27, 1995.
Marchi, L., Pasuto, A., and Tecca, P. R.: Flow processes on alluvial fans in the Eastern Italian Alps, Z. Geomorph., 4, 447-458, 1993.

Melton, M. A.: The geomorphic and paleoclimatic significance of alluvial deposits in southern Arizona, J. Geol., 73, 1-39, 1965.

National Research Council (NRC): Alluvial fan flooding, National Academy Press, 1-131, 1996.

Norbiato, D., Borga, M., Sangati, M., and Zanon, F.: Regional frequency analysis of extreme precipitation in the eastern Italian Alps and the August 29, 2003 flash flood, J. Hydrol., 345, 149166, 2007.

Norbiato, D., Borga, M., Degli Esposti, S., Gaume, E., and Anquetin, S.: Flash flood warning based on rainfall thresholds and soil moisture conditions: An assessment for gauged and ungauged basins, J. Hydrol., 362, 274-290, 2008.

Norbiato, D., Borga, M., and Dinaleb, R.: Flash flood warning in ungauged basins by use of the flash flood guidance and modelbased runoff thresholds, Meteorol. Appl., 16, 65-75, 2009.

Pasuto, A., Marchi, L., and Tecca, P. R.: Tipologia del trasporto solido torrentizio su conoidi alluvionali nell'alto bacino dell'Avisio (Dolomiti), Boll. Soc. Geol. It., 111, 41-51, 1992.

Ruin, I., Creutin, J. D., Anquetin, S., and Lutoff C.: Human exposure to flash floods - Relation between flood parameters and human vulnerability during a storm of September 2002 in Southern France, J. Hydrol., 361, 199-213, 2008.

Santangelo, N.: Evoluzione stratigrafica, geomorfologica e neotettonica di alcuni bacini lacustri del confine Campano Lucano (Italia Meridionale) - PHD thesis, III cycle, Earth sciences Department, University of Naples Federico II, Tipolitografica sud, Napoli, 1991.

Santangelo, N., Santo, A., and Faillace, P.: Valutazione della pericolosità alluvionale delle conoidi del Vallo di Diano (Salerno, Italia meridionale), Il Quaternario, 19, 3-17, 2006.

Schiermeier, Q.: Increased flood risk linked to global warming, Nature, 470, 316, 7334, doi:10.1038/470316a, 2011.

Spinelli, E.: Sala nel Settecento Spaccato di microgeografia storica, Salerno, Tip, Reggiani, 1983.

Van Dine, D. F.: Debris flow and debris torrents in the Southern Canadian Cordillera, Can. Geotech. J., 22, 44-68, 1985.

Van Westen, C. J.: The modelling of landslide hazards using GIS, in: Surveys in Geophysics, 21, 241-255, 2000.

Welsh, A. and Davies, T.: Identification of alluvial fans susceptible to debris-flow hazards, Landslides, 8, 183-194, doi:10.1007/s10346-010-0238-4, 2010. 